\title{
POST-APOCALYPTIC CONVERSATIONS WITH A SIDEWALK
}

\author{
A trip to remember.
}

\section{BY BETH CATO}

$\mathrm{E}$ mma tripped, but the sidewalk caught her. As her bony hip and shoulder met the concrete, the surface beneath her softened to the texture of the foam pads she had once used for tumbling exercises in school.

"Oh dear! I'm terribly sorry. It seems my third panel developed an uplift of four millimetres. I do hope you're all right. Should I summon assistance?" The voice was young, female and perky - though not obnoxious in a morning-talk-show-host kind of way. The sound came from the sidewalk itself.

Emma lay still, breathing fast in shock from the words, not the fall. "You ... the sidewalk, you talked?" Her voice was creaky with misuse. The surface hardened beneath her.

"Why, yes! I'm Cy Anara, the Friendly Sidewalk $^{\text {m }}$. Good morning. I apologize for the uplift that occurred while I was offline. It has now been corrected. Do you need emergency help?"

Emma rolled herself to a crouch and blinked tears from her eyes. How long had it been since she heard a human voice - even from a computer? She glanced around. The street was a ruin, like the rest of the city. A blackened sign read, '-OSPICE CARE. That explained the modified sidewalk. Her own grandpa had died when a fall and hip fracture led to pneumonia.

"Can you summon emergency care?" she asked.

"Yes!" A pause. "Oh dear. It seems that the network is currently down. The response status is not listed, but I've queued your request."

"It was worth a try. How ... how long were you offline?"

"It seems that I've been offline for seven months, five days and three hours. My average offline period is three hours, nine minutes."

No one had walked this way since the attack, then.

"I really am alone," she whispered. All alone here. Maybe in the country, the world. If the blasts hadn't killed them, the virus had.

"You're not alone. I will stay online as we await emergency responders."

How had the sidewalk's computer survived the EMP? Luck? Surely something like this hadn't been kept in a Faraday cage. She stroked the surface. It still felt like concrete but with the tiniest bit of give.
"Do you always talk to strangers?" A hysterical titter escaped her lips. She was talking! To a sidewalk!

"No one is a stranger to a Friendly Sidewalk!" said Cy. "I act as greeter for Twin Doves Hospice. I track a daily average of 53 residents and 22 regular guests to the facility. It's my hope that you'll become a regular, too!"

About half of the hospice had burned. Emma should investigate. She could always use more food and clothing for the stockpile, but she didn't want to move. She sprawled out on the sidewalk, quiet sobs shivering through her body, her backpack a heavy shell.

"I ... I'd like to become a regular. Can you tell me about Friendly Sidewalks? How large an area do you cover right here?"

"My sensors are distributed across ten panels of sidewalk directly in front of Twin Doves Hospice. I take care of my residents.

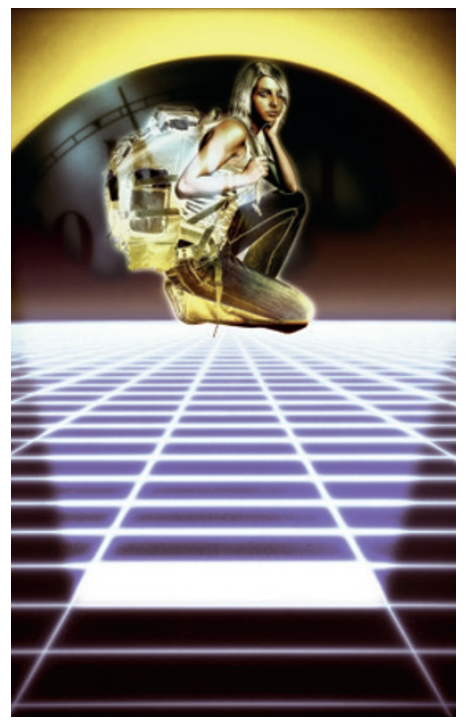
maintenance, but the problem is currently queued. I don't believe I heard a reply from you regarding more information on Friendly Sidewalks. Again, it's totally opt-in after the initial mailer!"

The sidewalk was cool against her cheek. Rough, porous, soothing. "Friendly Sidewalks. There are more of you?"

"Why, yes! I'm glad you asked. There are 12 Friendly Sidewalks within a 10 -mile radius. We're currently hosting a scavenger hunt. If you visit all 12 locations, you get an eco-friendly water bottle! Please visit our site for the full rules and regulations."

Emma scrambled to sit and unzipped her backpack. She cracked open a notebook warped by rain and tears. "The locations? Can you tell me?"

"Of course!"

If this one had survived, maybe some of the others had, too. Maybe they had As you're interested in Friendly Sidewalks, would you like to be sent an introductory document regarding our systems? We won't subscribe you unless you opt in!"

Ten panels. It'd be wonderful to bring the device home, but Emma had no idea how she would go about removing such an inlaid system. "You run on batteries? How ... how much power do you have left?"

"Yes, I run on batteries! My current battery life will keep me online for one hour, 13 minutes. Oh dear. It seems I'm overdue for my annual maintenance. I have queried the network. The system is currently down, but I'm sure a technician will respond shortly." A pause. "It's been three minutes since I requested emergency care for you. I apologize. I'm querying them again."

"One hour, 13 minutes." Emma moaned against her fist. "Please God, no. I want to $\rightarrow$ NATURE.COM

Follow Futures: y @NatureFutures

f go.nature.com/mtoodm talk longer than that."

"I apologize for the limits of my battery. This should have been addressed in my more juice in their batteries. She scribbled down the addresses and filled two pages. "How much battery life is left now?"

"One hour, five minutes remaining. The maintenance system is currently unresponsive. I've queried again. Do you still need emergency care?"

Yes. Emma stood. "No ... I, I'm going to go now. I need to go. I can't ... I can't use you up all in one shot. I'll be back tomorrow. I promise. I'll be a regular." She stepped into the gutter. "Bye."

"I'm glad we're friends! Good-bye, from Cy Anara, the Friendly Sidewalk!"

Silence.

Emma stared at the sidewalk for a few minutes and then hurried on, notebook in hand. Food could wait.

She had more friends to find.

Beth Cato resides in Arizona. Her debut novel, The Clockwork Dagger, was released by HarperCollins Voyager US in September 2014. Her website is www. bethcato.com. 